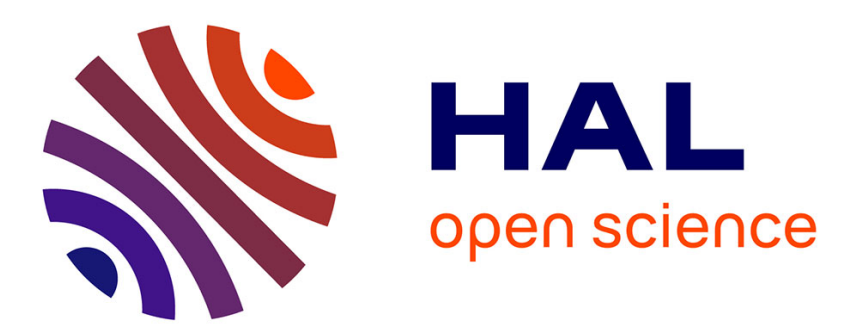

\title{
New approach of laser diode pumping of solid state lasers for gravitational wave measurements
}

\author{
K.-I. Ueda, N. Uehara
}

\section{To cite this version:}

K.-I. Ueda, N. Uehara. New approach of laser diode pumping of solid state lasers for gravitational wave measurements. Journal de Physique IV Proceedings, 1994, 04 (C4), pp.C4-593-C4-593. 10.1051/jp4:19944144 . jpa-00252599

\section{HAL Id: jpa-00252599 https://hal.science/jpa-00252599}

Submitted on 1 Jan 1994

HAL is a multi-disciplinary open access archive for the deposit and dissemination of scientific research documents, whether they are published or not. The documents may come from teaching and research institutions in France or abroad, or from public or private research centers.
L'archive ouverte pluridisciplinaire HAL, est destinée au dépôt et à la diffusion de documents scientifiques de niveau recherche, publiés ou non, émanant des établissements d'enseignement et de recherche français ou étrangers, des laboratoires publics ou privés. 


\title{
New approach of laser diode pumping of solid state lasers for gravitational wave measurements
}

\author{
K.-I. UEDA and N. UEHARA \\ Institute for Laser Science, Univ. of Electro-Communications, Chofu, Tokyo 182, Japan
}

\begin{abstract}
A new scalable side pumping geometry of solid state lasers by means of multi laserdiodes (LDs) has been developed related to the gravitational wave detection. Multi-LD beams concentrated onto the optical axis of a laser rod forms a virtual point or line source for rod pumping. A cylindrical cavity for LD pumping allows the multipass excitation of coaxially arranged rod in a form of image relay configuration. In this geometry the image deformation of virtual point source is minimized so that efficient multi-pass excitation is possible. Multi-pass excitation allows the effective pumping of optically thin materials in a manner of center-core pumping. The geometrical factor of conversing beam excitation is effective to concentrate the pumping power at the center of rod. Theoretical and experimental analyses have been investigated by using thirtytwo channels of fiber-coupled LDs. High efficiency single mode performance has been demonstrated successfully. The high power version of this geometry under development will be discussed related to the future plan of gravitational wave detection.
\end{abstract}

